\title{
Publications, Presentations, and Awards (ORNL/CDIAC-101)
}

Compiled by Robert M. Cushman (updated December 2001)

This publication lists

- journal articles,

- book and proceedings chapters,

- numeric data packages and online data bases, and

- other Oak Ridge National Laboratory (ORNL) and U.S. Department of Energy (DOE) reports published by the Carbon Dioxide Information Analysis Center (CDIAC);

- presentations of CDIAC staff; and

- awards presented to CDIAC since its inception in 1982.

Please note that not all publications listed here are currently available; for a complete listing of available publications and data bases, please check our current Catalog of Databases and Reports (ORNL/CDIAC-34) or online listing of products.

\section{Journal Articles}

Andres, R.J., T.A. Boden, and G. Marland. 1994. Carbon dioxide emissions from fossil fuel production in 1992. Eos 75:152.

Andres, R.J., D.J. Fielding, G. Marland, T.A. Boden, and N. Kumar. 1999. Carbon dioxide emissions from fossil-fuel use, 1751-1950. Tellus 51B:759-765.

Andres, R.J., G. Marland, I. Fung, and E. Matthews. 1996. A $1^{\circ}$ x $1^{\circ}$ distribution of carbon dioxide emissions from fossil fuel consumption and cement manufacture, 1950-1990. Global Biogeochemical Cycles 10(3):419-429.

Cushman, R.M. 1991. Some challenges in the use of general circulation model output in climate-impact studies. The Environmental Professional 13(1):16-24.

Cushman, R.M., M.P. Farrell, and F.A. Koomanoff. 1988. Climate and regional resource analysis: The effect of scale on resource homogeneity. Climatic Change 13(2):129-148.

Cushman, R.M., and P.N. Spring. 1989. Differences among model simulations of climate change on the scale of resource regions. Environmental Management 13(6):789-795.

Cushman, R.M., and F.W. Stoss. 1993. Institutions: Carbon Dioxide Information Analysis Center. Environment 35(3):5.

Daniels, R.C. 1992. Sea-level rise on the South Carolina coast: Two case studies for 2100. Journal of Coastal Research 8(1):56-70.

Daniels, R.C. 1996. An innovative method of model integration to forecast spatial patterns of shoreline change: A case study of Nags Head, North Carolina. Professional Geographer 48(2):195-209.

Daniels, R.C., T.W. White, and K.K. Chapman. 1993. Sea-level rise: Destruction of threatened and endangered species habitat in South Carolina. Environmental Management 17(3):373-385.

DeAngelis, D.L., and R.M. Cushman. 1990. Potential application of models in forecasting the effects of climate changes on fisheries. Transactions of the American Fisheries Society 119(2):224-239.

Gornitz, V.M., R.C. Daniels, T.W. White, and K.R. Birdwell. 1994. The development of a coastal risk assessment database: Vulnerability to sea-level rise in the U.S. Southeast. Journal of Coastal Research 12:327-338.

Kaiser, D.P. 1998. Analysis of total cloud amount over China, 1951-1994. Geophysical Research Letters 25(19):3599-3602. 
Kaiser, D.P. 2000. Decreasing cloudiness over China: An updated analysis examining additional variables. Geophysical Research Letters 27(15):2193-2196.

Marland, G., T. Boden, and R.J. Andres. 1995. Carbon dioxide emissions from fossil fuel burning: Emissions coefficients and the global contribution from Eastern European countries. Idójárás (Quarterly Journal of the Hungarian Meteorological Service) 99(3-4):157-170.

Marland, G., A. Brenkert, and J. Olivier. 1999. $\mathrm{CO}_{2}$ from fossil fuel burning: a comparison of ORNL and EDGAR estimates of national emissions. Environmental Science \& Policy 2:265-273.

Schuhardt, S.L., R.M. Cushman, and T.A. Boden. 1989. A county-level approach to resource analysis based on climate simulation. Journal of Climate 2(2):113-120.

Scott, M.J., N.J. Rosenberg, J.A. Edmonds, R.M. Cushman, R.F. Darwin, G.W. Yohe, A.M. Liebetrau, C.T. Hunsaker, D.A. Bruns, D.L. DeAngelis, and J.M. Hales. 1990. Consequences of climatic change for the human environment. Climate Research 1(1):63-79.

Stoss, F.W. 1992. The Carbon Dioxide Information Analysis Center: Responding to changing information needs. Green Library Journal 1 (3):3-13.

Stoss, F.W. 1995. The Carbon Dioxide Information Analysis Center. Country Study Notes 3:2-3.

Stoss, F.W. 1996. Managing global change information. Oak Ridge National Laboratory Review 28(2-3):30-39.

\section{Books and Proceedings Chapters}

Andres, R.J., G. Marland, T. Boden, and S. Bischof. 2000. Carbon dioxide emissions from fossil fuel combustion and cement manufacture, 1751-1991 and an estimate of their isotopic composition and latitudinal distribution, p. 53-62, IN The Carbon Cycle, T.M.L. Wigley and D.S. Schimel (eds.). Cambridge University Press, Cambridge, U.K.

Aronson, E., D. Barns, S. Barr, C. Bloyd, D. Bruns, R. Cushman, R. Darwin, D. DeAngelis, M. Edenburn, J. Edmonds, W. Emanuel, D. Engi, M. Farrell, J. Hales, E. Hillsman, C. Hunsaker, A. King, A. Liebetrau, M. MacCracken, B. Manowitz, G. Marland, S. McDonald, J. Penner, S. Rayner, N. Rosenberg, M. Scott, M. Steinberg, W. Westman, D. Wuebbles, and G. Yohe. 1990. Energy and Climate Change (Report of the DOE Multi-Laboratory Climate Change Committee). Lewis Publishers, Chelsea, Michigan.

Boden, T.A. 1995. Metadata compiled and distributed by the Carbon Dioxide Information Analysis Center for global climate change and greenhouse gas-related data bases, p. 13-18, IN The Role of Metadata in Managing Large Environmental Science Datasets, R.B. Melton, D.M. DeVaney, and J.C. French (eds.). Pacific Northwest Laboratory, Richland, Washington.

Boden, T.A., D.P. Kaiser, R.J. Sepanski, L.J. Morris, D.E. Shepherd, and S.B. Jones. 1993. Data archival, documentation, and distribution activities performed by the Carbon Dioxide Information Analysis Center, p. 8, IN Proceedings of the PRC/CAS - US/DOE Sixth Science Team Meeting, Joint Research on the Greenhouse Effect. Chinese Academy of Sciences, Beijing.

Boden, T.A., G. Marland, and R.J. Andres. 1996. $\mathrm{CO}_{2}$ emission calculations and trends, p. 18-34, IN Proceedings, 1995 Symposium on Greenhouse Gas Emissions and Mitigation Research. Environmental Protection Agency, Washington, D.C.

Cushman, R.M. 1991. Using climate model output to assess the impacts of climate change on water resources, p. 679-83, IN Water Resources: Planning and Management and Urban Water Resources, J.L. Anderson (ed.). American Society of Civil Engineers, New York.

Cushman, R.M. 1999. Global climatic-change modeling and monitoring, p. 291-98, IN Encyclopedia of Environmental Science, D.E. Alexander and R.W. Fairbridge (eds.). Kluwer Academic Publishers, Dordrecht, Boston, and London.

Cushman, R.M., J.J. Beauchamp, and A.L. Brenkert. 1999. Validating CDIAC's population-based approach to the disaggregation of withincountry $\mathrm{CO}_{2}$ emissions, p. 374-85, IN Global Climate Change: Science, Policy, and Mitigation/Adaptation Strategies, J. Kinsman, C.V. Mathai, M. Baer, E. Holt, and M. Trexler (eds.). Air \& Waste Management Association, Pittsburgh.

Cushman, R.M., T.A. Boden, M.P. Farrell, S.B. Jones, D.P. Kaiser, P. Kanciruk, E.E. Mitchell, T.R. Nelson, and R.J. Sepanski. 1999. Retrospective on CDIAC's Activities in United States-China Research on the Greenhouse Effect, p. 122-27, IN Greenhouse Effect and Climate Change, S.Y. Tao, M.R. Riches, P.Q. Chen, and W.C. Wang (eds.). China Ocean Press, Beijing.

Cushman, R.M., D.B. Hunsaker Jr., M.S. Salk, and R.M. Reed. 1993. Global climate change and NEPA analyses, p. 442-62, IN 
Environmental Analysis: The NEPA Experience, S.G. Hildebrand and J.B. Cannon (eds.). Lewis Publishers, Boca Raton, Florida.

Cushman, R.M., J.C. Waterhouse, and M.P. Farrell. 1987. Climate predictions, regions, and resources, p. 127-32, IN Monitoring and Managing Environmental Impact, G.E. Schweitzer and A.S. Phillips (eds.). National Research Council, Washington, D.C.

Daniels, R.C., E.P. Flint, and J.F. Richards. 1994. Deforestation and carbon estimates for South and Southeast Asia: 1880-1980, p. 74, IN Proceedings, Ninetieth Annual Meeting, Association of American Geographers. Association of American Geographers, Washington, D.C.

Gornitz, V., and P. Kanciruk. 1989. Assessment of global coastal hazards from sea level rise, p. 1345-59, IN Coastal Zone '89. American Society of Civil Engineers, New York, New York.

Gornitz, V., and T.W. White. 1991. The Global Coastal Hazards Data Base, p. 214-24, IN Future Climate Studies amd Radio-Active Waste Disposal. Norwich, England.

Gornitz, V., T.W. White, and R.M. Cushman. 1991. Vulnerability of the U.S. to future sea level rise, p. 2354-68, IN Coastal Zone '91. American Society of Civil Engineers, New York, New York.

Jones, S.B., L.J. Morris, D.E. Shepherd, and T.W. Stamm. 1993. CDIAC's PC-based information management system, IN Proceedings, Tenth Office Information Technology Conference, multimedia CD. Martin Marietta Energy Systems, Oak Ridge, Tennessee.

Kaiser, D.P. 1993. Cloud amount and sunshine duration in the People's Republic of China, 1954-88, p. 224-32, IN Proceedings, Eighth Conference on Applied Climatology. American Meteorological Society, Boston, Massachusetts.

Kaiser, D.P., and V.N. Razuvaev. 1995. Cloud cover and type over the former USSR, 1936-83: Trends derived from the RIHMI-WDC 223-station 6- and 3-hourly meteorological database, p. 419-42, IN Proceedings of the Sixth International Meeting on Statistical Climatology. University College, Galway, Ireland.

Kaiser, D.P., R.S. Vose, T.R. Karl, and V.N. Razuvaev. 1995. The distribution of cloud cover over the former USSR as derived from the RIHMI 223-station 3-hourly meteorological climatology database, p. 81-86, IN Proceedings, Ninth Conference on Applied Climatology. American Meteorological Society, Boston, Massachusetts.

Marland, G., and T.A. Boden. 1993. The magnitude and distribution of fossil-fuel-related carbon releases, p. 117-38, IN The Global Carbon Cycle, Vol. I 15, M. Heimann (ed.), NATO ASI Series. Springer-Verlag, Berlin.

Marland, G., T. Boden, and R.J. Andres. 1995. Fossil fuels and atmospheric carbon dioxide: Past, present, future, p. 71-72, IN Abstracts with Programs, Vol. 27, No. 2. Geological Society of America, Boulder, Colorado.

Marland, G., T. Boden, A. Brenkert, and R.J. Andres. 1999. Historical and projected global greenhouse gas emissions, p. 37-42, IN Global Climate Change: Science, Policy, and Mitigation/Adaptation Strategies, J. Kinsman, C.V. Mathai, M. Baer, E. Holt, and M. Trexler (eds.). Air \& Waste Management Association, Pittsburgh.

Peterson, T.C., D.R. Easterling, R.S. Vose, and J.K. Eischeid. 1993. The Global Historical Climatology Network precipitation data, p. 8287, IN Proceedings, Symposium on Precipitation and Evaporation, Vol. I: Precipitation Measurement and Quality Control. Slovak Hydrometeorological Institute, Bratislava, Slovakia.

Peterson, T.C., D.R. Easterling, R.S. Vose, and J.K. Eischeid. 1994. Homogeneous global mean temperature time series, p. 173-74, IN Proceedings, Sixth Conference on Climate Variations, Nashville, Tennessee, January 1994. American Meteorological Society, Boston, Massachusetts.

Peterson, T.C., and R.S. Vose. 1992. The Global Historical Climatology Network: Present and future, p. 172-77, IN Proceedings, Seventeenth Annual Climate Diagnostics Workshop. U.S. Department of Commerce, Washington, D.C.

Stoss, F.W. 1991. CDIAC: Responding to Changing Information Needs, p. 182, IN Abstracts, Eighty-Fourth Annual Meeting and Exhibition, Air and Waste Management Association. Air and Waste Management Association, Pittsburgh, Pennsylvania.

Stoss, F.W. 1992. The Carbon Dioxide Information Analysis Center: Providing support for DOE's Global Change Research Program, p. 105-9, IN Infotech 1992, CONF-9210158, DE93000467. U.S. Department of Energy, Office of Scientific and Technical Information, Oak Ridge, Tennessee.

Vose, R.S. 1992. Compilation of long-term monthly temperature, precipitation, and pressure data, IN Book of Abstracts, Annual Meeting of 
the Association of American Geographers. Association of American Geographers, Washington, D.C.

Vose, R.S., T.C. Peterson, R.L. Schmoyer, and J.K. Eischeid. 1995. The Global Historical Climatology Network: A Preview of Version 2, p. 59-64, IN Proceedings, Ninth Conference on Applied Climatology. American Meteorological Society, Boston, Massachusetts.

Vose, R.S., T.C. Peterson, R.L. Schmoyer, J.K. Eischeid, P.M. Steurer, R. Heim, and T.R. Karl. 1993. The Global Historical Climatology Network: Long-term monthly temperature, precipitation, and pressure data, p. 312-17, IN Proceedings, Fourth Symposium on Global Change Studies. American Meteorological Society, Boston.

\section{Numeric Data Packages and Online Data Bases}

Andres, R.J., G. Marland, and S. Bischof. 1996. Global and Latitudinal Estimates of $d^{13}$ C from Fossil-Fuel Consumption and Cement Manufacture, DB1013 (T.A. Boden, editor). Oak Ridge National Laboratory, Oak Ridge, Tennessee.

Andres, R.J., G. Marland, I. Fung, and E. Matthews. 1997. Geographic Patterns of Carbon Dioxide Emissions from Fossil-Fuel Burning, Hydraulic Cement Production, and Gas Flaring on a One Degree by One Degree Grid Cell Basis: 1950 to 1990, ORNL/CDIAC-97, NDP058 (A.L. Brenkert, editor). Oak Ridge National Laboratory, Oak Ridge, Tennessee.

Angell, J.K. 1997. Annual and Seasonal Global Temperature Anomalies in the Troposphere and Low Stratosphere, 1958-1996, NDP-008 (D.P. Kaiser and T.A. Boden, editors). Oak Ridge National Laboratory, Oak Ridge, Tennessee.

Angell, J.K., J. Korshover, and W.G. Planet. 1991. Annual and Seasonal Global Variation in Total Ozone and Layer-Mean Ozone, 19581987, NDP-023. Oak Ridge National Laboratory, Oak Ridge, Tennessee.

Arking, A., B. Ridgway, T. Clough, M. Iacono, B. Fomin, A. Trotsenko, S. Freidenreich, and D. Schwarzkopf. 1994. ICRCCM Infrared (Clear-Sky) Line-by-Line Radiative Fluxes, DB1002. Oak Ridge National Laboratory, Oak Ridge, Tennessee.

Auclair, A.N.D., J.A. Bedford, and C. Revenga. 1997. Northern Hemisphere Biome-and Process-Specific Changes in Forest Area and Gross Merchantable Volume: 1890-1990, DB1017 (A.L. Brenkert, editor). Oak Ridge National Laboratory, Oak Ridge, Tennessee.

Beardsmore, D.J., and G.I. Pearman. 1984. Atmospheric $\mathrm{CO}_{2}$ Concentrations - The CSIRO (Australia) Monitoring Program from Aircraft for 1972-1981, NDP-007. Oak Ridge National Laboratory, Oak Ridge, Tennessee.

Beardsmore, D.J., G.I. Pearman, and R.C. O'Brien. 1985. Atmospheric $\mathrm{CO}_{2}$ Concentrations - The CSIRO Monitoring Program: Surface Data for Cape Grim, Tasmania, NDP-010. Oak Ridge National Laboratory, Oak Ridge, Tennessee.

Birdwell, K.R., and R.C. Daniels. 1991. A Global Geographic Information System Data Base of Storm Occurrences and Other Climatic Phenomena Affecting Coastal Zones, ORNL/CDIAC-40, NDP-035. Oak Ridge National Laboratory, Oak Ridge, Tennessee.

Blasing, T.J., and D.N. Duvick. 1984. Tree Ring Chronology Indexes and Reconstructions of Precipitation in Central Iowa, USA, NDP002. Oak Ridge National Laboratory, Oak Ridge, Tennessee.

Bradley, R.S., L.G. Ahern, and F.T. Keimig. 1994. A Computer-Based Atlas of Global Instrumental Climate Data, DB1003. Oak Ridge National Laboratory, Oak Ridge, Tennessee.

Bradley, R.S., P.M. Kelly, P.D. Jones, C.M. Goodess, and H.F. Diaz. 1985. Climatic Data for Northern Hemisphere Land Areas: 18511980, NDP-012. Oak Ridge National Laboratory, Oak Ridge, Tennessee.

Brenkert, A.L. 1998. Carbon Dioxide Emission Estimates from Fossil-Fuel Burning, Hydraulic Cement Production, and Gas Flaring for 1995 on a One Degree Grid Cell Basis, NDP-058A. Oak Ridge National Laboratory, Oak Ridge, Tennessee.

Brewer, P.G., T. Takahashi, and R.T. Williams. 1986. Transient Tracers in the Oceans (TTO) Hydrographic Data and Carbon Dioxide Systems with Revised Carbon Chemistry Data, NDP-004. Oak Ridge National Laboratory, Oak Ridge, Tennessee.

Brounshtein, A.M., E.V. Faber, and A.A. Shashkov. 1994. Atmospheric $\mathrm{CO}_{2}$ Concentrations Derived from Flask Samples Collected At U.S.S.R.-Operated Sampling Sites, ORNL/CDIAC-51, NDP-033 (T.A. Boden, editor). Oak Ridge National Laboratory, Oak Ridge, Tennessee.

Brown, S., and G. Gaston. 1996. Tropical Africa: Land Use, Biomass, and Carbon Estimates for 1980 With a Method for Extending the 
Data to 1990 and Beyond, ORNL/CDIAC-92, NDP-055 (R.C. Daniels, editor). Oak Ridge National Laboratory, Oak Ridge, Tennessee.

Brown, S., L.R. Iverson, and A. Prasad. 2001. Geographical Distribution of Biomass Carbon in Tropical Southeast Asian Forests: A Database, ORNL/CDIAC-119, NDP-068 (T.W. Beaty, L.M. Olsen, R.M. Cushman, and A.L. Brenkert, editors). Oak Ridge National Laboratory.

Chen, C.-T.A. 1988. Carbonate Chemistry of the Weddell Sea, NDP-028. Oak Ridge National Laboratory, Oak Ridge, Tennessee.

Chen, C.-T.A., M.R. Rodman, C.-L. Wei, E.J. Olson, R.A. Feely, and J.F. Gendron. 1988. Carbonate Chemistry of the North Pacific Ocean, NDP-029. Oak Ridge National Laboratory, Oak Ridge, Tennessee.

Chipman, D.W., T. Takahashi, D. Berger, and S.C. Sutherland. 1994. Carbon Dioxide, Hydrographic, and Chemical Data Obtained During the $R / V$ Meteor Cruise 11/5 in the South Atlantic and Northern Weddell Sea Areas (WOCE sections A-12 and A-21), ORNL/CDIAC-55, NDP-045 (A. Kozyr, and A.F. Gaslightwala, editors). Oak Ridge National Laboratory, Oak Ridge, Tennessee.

Chipman, D.W., T. Takahashi, S. Rubin, S.C. Sutherland, and M. Koshlyakov. 1997. Carbon Dioxide, Hydrographic, and Chemical Data Obtained During the R/V Akademik Ioffe Cruise in the South Pacific Ocean (WOCE Section S4P, February-April 1992), ORNL/CDIAC100, NDP-063 (A. Kozyr, editor). Oak Ridge National Laboratory, Oak Ridge, Tennessee.

Christensen, S.W., T.A. Boden, L.A. Hook, and M.-D. Cheng. 1999. NARSTO Data Management Handbook, ORNL/CDIAC-112. Oak Ridge National Laboratory, Oak Ridge, Tennessee.

Conway, T.J., and P. Tans. 1996. Atmospheric Carbon Dioxide Mixing Ratios from the NOAA Climate Monitoring and Diagnostics Laboratory Cooperative Flask Sampling Network, 1967-993, ORNL/CDIAC-73, NDP-005 (T.A. Boden, editor). Oak Ridge National Laboratory, Oak Ridge, Tennessee.

Curtis, P.S. 1997. A Comprehensive Database of Woody Vegetation Responses to Elevated Atmospheric CO 2 , DB1018 (A.L. Brenkert, editor). Oak Ridge National Laboratory, Oak Ridge, Tennessee.

Curtis, P.S. 1999. A Database of Woody Vegetation Responses to Elevated Atmospheric CO, ORNL/CDIAC-120, NDP-072 (R.M. Cushman and A.L. Brenkert, preparers). Oak Ridge National Laboratory, Oak Ridge, Tennessee.

Dickson, A.G., C.D. Keeling, P.R. Guenther, and J.L. Bullister. 2000. Carbon Dioxide, Hydrographic, and Chemical Data Obtained During the R/V John V. Vickers Cruise in the Pacific Ocean (WOCE Section P13, NOAA CGC92 Cruise, August 4 - October 21, 1992), ORNL/CDIAC-128, NDP-075 (A. Kozyr, editor). Oak Ridge National Laboratory, Oak Ridge, Tennessee.

Dlugokencky, E.J., P.M. Lang, K.A. Masarie, and L.P. Steele. 1994. Atmospheric Methane Mixing Ratios - The NOAA/CMDL Global Cooperative Air Sampling Network, 1983-1993, DB1008. Oak Ridge National Laboratory, Oak Ridge, Tennessee.

Easterling, D.R., P. Jamason, D.P. Bowman, P.Y. Hughes, and E.H. Mason. 1997. Daily Snow Depth Measurements from 195 Stations in the United States, ORNL/CDIAC-95, NDP-059 (L.J. Allison, editor). Oak Ridge National Laboratory, Oak Ridge, Tennessee.

Easterling, D.R., T.R. Karl, J.H. Lawrimore, and S.A. Del Greco. 1999. United States Historical Climatology Network Daily Temperature, Precipitation, and Snow Data(1871-1997), ORNL/CDIAC-118, NDP-070 (D.P. Kaiser and L.J. Allison, editors). Oak Ridge National Laboratory, Oak Ridge, Tennessee.

Easterling, D.R., T.R. Karl, E.H. Mason, P.Y. Hughes, and D.P. Bowman. 1996. United States Historical Climatology Network (U.S. HCN) Monthly Temperature and Precipitation Data, ORNL/CDIAC-87, NDP-019 (R.C. Daniels and T.A. Boden, editors). Oak Ridge National Laboratory, Oak Ridge, Tennessee.

Edmonds, J.A., J.M. Reilly, and D.W. Barns. 1995. The IEA/ORAU Long-Term Global Energy-CO 2 Model: Personal Computer Version $A 84 P C$, CMP002PC. Oak Ridge National Laboratory, Oak Ridge, Tennessee.

Enting, I.G., T.M.L. Wigley, and M. Heimann. 1995. Intergovernmental Panel on Climate Change (IPCC), Working Group 1, 1994: Modelling Results Relating Future Atmospheric $\mathrm{CO}_{2}$ Concentrations to Industrial Emissions, DB1009. Oak Ridge National Laboratory, Oak Ridge, Tennessee.

Francey, R.J., P.P. Tans, C.E. Allison, I.G. Enting, J.W.C. White, and M. Trolier. 1996. In situ Carbon 13 and Oxygen 18 Ratios of Atmospheric $\mathrm{CO}_{2}$ from Cape Grim, Tasmania, Australia: 1982-1993, DB1014 (T.A. Boden, editor). Oak Ridge National Laboratory, Oak Ridge, Tennessee. 
Fung, I. 1993. Goddard Institute for Space Studies (GISS) 3-Dimensional (3-D) Global Tracer Transport Model, DB1006. Oak Ridge National Laboratory, Oak Ridge, Tennessee.

Gornitz, V.M., T.W. Beaty, and R.C. Daniels. 1997. A Coastal Hazards Data Base for the U.S. West Coast, ORNL/CDIAC-81, NDP043C. Oak Ridge National Laboratory, Oak Ridge, Tennessee.

Gornitz, V.M., and T.W. White. 1992. A Coastal Hazards Data Base for the U.S. East Coast, ORNL/CDIAC-45, NDP-043A (R.C. Daniels, editor). Oak Ridge National Laboratory, Oak Ridge, Tennessee.

Gornitz, V.M., and T. W. White. 1994. A Coastal Hazards Data Base for the U.S. Gulf Coast, ORNL/CDIAC-60, NDP-043B (R.C. Daniels, editor). Oak Ridge National Laboratory, Oak Ridge, Tennessee.

Goyet, C., P.R. Guenther, C.D. Keeling, and L.D. Talley. 1996. Carbon Dioxide, Hydrographic, and Chemical Data Obtained During the $R / V$ Thomas Washington Cruise TUNES-3 in the Equatorial Pacific Ocean (WOCE Section P16C), ORNL/CDIAC-96, NDP-060 (A. Kozyr, editor). Oak Ridge National Laboratory, Oak Ridge, Tennessee.

Goyet, C., R. Healy, and J. Ryan. 2000. Global Distribution of Total Inorganic Carbon and Total Alkalinity Below the Deepest Winter Mixed Layer Depths, ORNL/CDIAC-127, NDP-076 (A. Kozyr, editor). Oak Ridge National Laboratory, Oak Ridge, Tennessee.

Goyet, C., R.M. Key, and M. Tsuchiya. 1997. Carbon Dioxide, Hydrographic, and Chemical Data Obtained During the R/V Thomas Washington Cruise TUNES 1 in the Equatorial Pacific Ocean (WOCE Section P17C), ORNL/CDIAC-99, NDP-062 (A. Kozyr, editor). Oak Ridge National Laboratory, Oak Ridge, Tennessee.

Hahn, C.J., and S.G. Warren. 1999. Extended Edited Synoptic Cloud Reports from Ships and Land Stations Over the Globe, 1952-1996, ORNL/CDIAC-123, NDP-026C. Oak Ridge National Laboratory, Oak Ridge, Tennessee.

Hahn, C.J., S.G. Warren, and J. London. 1994. Climatological Data for Clouds Over the Globe from Surface Observations, 1982-1991, ORNL/CDIAC-72, NDP-026A. Oak Ridge National Laboratory, Oak Ridge, Tennessee.

Hahn, C.J., S.G. Warren, and J. London. 1996. Edited Synoptic Cloud Reports from Ships and Land Stations Over the Globe, 1982-1991, ORNL/CDIAC-77, NDP-026B (L.J. Morris and T.A. Boden, editors). Oak Ridge National Laboratory, Oak Ridge, Tennessee.

Hahn, C.J., S.G. Warren, J. London, R.L. Jenne, and R.M. Chervin. 1988. Climatological Data for Clouds Over the Globe from Surface Observations, NDP-026. Oak Ridge National Laboratory, Oak Ridge, Tennessee.

Hanson, P.J., D.E. Todd, J.S. Riggs, M.E. Wolfe, and E.G. O'Neill. 2001. Walker Branch Throughfall Displacement Experiment Data Report: Site Characterization, System Performance, Weather, Species Composition, and Growth, ORNL/CDIAC-134, NDP-078A (R.M. Cushman, editor). Oak Ridge National Laboratory, Oak Ridge, Tennessee.

Hook, L.A., M.-D. Cheng, and T.A. Boden. 1998. NARSTO Quality Planning Handbook, ORNL/CDIAC-111. Oak Ridge National Laboratory, Oak Ridge, Tennessee.

Houghton, R.A., and J.L. Hackler. 2001. Carbon Flux to the Atmosphere from Land-Use Changes: 1850 to 1990, ORNL/CDIAC-131, NDP-050/R1 (R. M. Cushman, editor). Oak Ridge National Laboratory, Oak Ridge, Tennessee.

Hoyt, D.V. 1985. Solar Records: The Wold Sunspot Index and Umbral/Penumbral Ratio, NDP-014. Oak Ridge National Laboratory, Oak Ridge, Tennessee.

Hughes, P.Y., E.H. Mason, T.R. Karl, and W.A. Brower. 1995. United States Historical Climatology Network Daily Temperature and Precipitation Data, ORNL/CDIAC-50, NDP-042 (D.P. Kaiser, editor). Oak Ridge National Laboratory, Oak Ridge, Tennessee.

Johnson, D.W., J.T. Ball, and R.F. Walker. 1998. Effects of $\mathrm{CO}_{2}$ and Nitrogen Fertilization on Growth and Nutrient Content of Juvenile Ponderosa Pine, ORNL/CDIAC-107, NDP-061A (R.M. Cushman, editor). Oak Ridge National Laboratory, Oak Ridge, Tennessee.

Johnson, K.M., M. Haines, R.M. Key, C. Neill, B. Tilbrook, R. Wilke, and D.W.R. Wallace. 2001. Carbon Dioxide, Hydrographic, and Chemical Data Obtained During the R/V Knorr Cruise 138-3, -4, and -5 in the South Pacific Ocean (WOCE Sections P6E, P6C, and P6W, May 2 - July 30, 1992), ORNL/CDIAC-132, NDP-077 (A. Kozyr and T.W. Beaty, editors). Oak Ridge National Laboratory, Oak Ridge, Tennessee.

Johnson, K.M., B. Schneider, L. Mintrop, and D.W.R. Wallace. 1996. Carbon Dioxide, Hydrographic, and Chemical Data Obtained 
During the R/V Meteor Cruise 18/1 in the North Atlantic Ocean (WOCE Section A1E, September 1991), ORNL/CDIAC-91, NDP-056 (A. Kozyr, editor). Oak Ridge National Laboratory, Oak Ridge, Tennessee.

Johnson, K.M., B. Schneider, L. Mintrop, and D.W.R. Wallace. 1998. Carbon Dioxide, Hydrographic, and Chemical Data Obtained During the R/V Meteor Cruise 22/5 in the South Atlantic Ocean (WOCE Section A10, December 1992 - January 1993), ORNL/CDIAC113, NDP-066 (A. Kozyr, editor). Oak Ridge National Laboratory, Oak Ridge, Tennessee.

Johnson, K.M., D.W.R. Wallace, R.J. Wilke, and C. Goyet. 1995. Carbon Dioxide, Hydrographic, and Chemical Data Obtained During the $R / V$ Meteor Cruise 15/3 in the South Atlantic Ocean (WOCE Section A9, February-March 1991), ORNL/CDIAC-82, NDP-051 (A. Kozyr, editor). Oak Ridge National Laboratory, Oak Ridge, Tennessee.

Jones, M.H., and P.S. Curtis. 1999. A Database of Herbaceous Vegetation Responses to Elevated Atmospheric CO 2 , ORNL/CDIAC-124, NDP-073 (R.M. Cushman and A.L. Brenkert, preparers). Oak Ridge National Laboratory, Oak Ridge, Tennessee.

Jones, P.D., S.C.B. Raper, B.S.G. Cherry, C.M. Goodess, T.M.L. Wigley, B. Santer, P.M. Kelly, R.S. Bradley, and H.F. Diaz. 1991. An Updated Global Grid Point Surface Air Temperature Anomaly Data Set: 1851-1990, ORNL/CDIAC-37, NDP-020. Oak Ridge National Laboratory, Oak Ridge, Tennessee.

Jones, P.D., S.C.B. Raper, P.M. Kelly, T.M.L. Wigley, H.F. Diaz, and R.S. Bradley. 1986. Global Surface-Air Temperature Variations: 1851-1984, NDP-003. Oak Ridge National Laboratory, Oak Ridge, Tennessee.

Jones, P.D., and P.A. Reid. 2001. A Databank of Antarctic Surface Temperature and Pressure Data, ORNL/CDIAC-27, NDP-032 (D.P. Kaiser, editor). Oak Ridge National Laboratory, Oak Ridge, Tennessee.

Jones, P.D., T.M.L. Wigley, and K.R. Briffa. 1987. Monthly Mean Pressure Reconstructions for Europe (1780-1980) and North America (1858-1980), NDP-025. Oak Ridge National Laboratory, Oak Ridge, Tennessee.

Jones, P.D., T.M.L. Wigley, and P.B. Wright. 1994. Global and Hemispheric Annual Temperature Variations Between 1861 and 1991 , NDP-022. Oak Ridge National Laboratory, Oak Ridge, Tennessee.

Karl, T.R., R.G. Baldwin, M.G. Burgin, D.R. Easterling, R.W. Knight, and P.Y. Hughes. 1994. Alaskan Historical Climatology Network $(H C N)$ Serial Temperature and Precipitation Data, DB1004. Oak Ridge National Laboratory, Oak Ridge, Tennessee.

Karl, T.R., and F.T. Quinlan. 1985. Climatic Data for Selected U.S. and Canadian Stations 1941-1980, NDP-016. Oak Ridge National Laboratory, Oak Ridge, Tennessee.

Keeling, C.D., and T.P. Whorf. 2001. Atmospheric $\mathrm{CO}_{2}$ Concentrations--Mauna Loa Observatory, Hawaii, 1958-2000, NDP-001. Oak Ridge National Laboratory, Oak Ridge, Tennessee.

Khalil, M.A.K., and R.A. Rasmussen. 1994. Atmospheric Methane at Cape Meares, Oregon, U.S.A.: A High-Resolution Data Base for the Period 1979-1992, DB1007. Oak Ridge National Laboratory, Oak Ridge, Tennessee.

Khalil, M.A.K., and R.A. Rasmussen. 1995. Globally Averaged Atmospheric CFC-11 Concentrations: Monthly and Annual Data for the Period 1975-1992, DB1010. Oak Ridge National Laboratory, Oak Ridge, Tennessee.

Kimball, B.A., J.R. Mauney, R.L. LaMorte, G. Guinn, F.S. Nakayama, J.W. Radin, E.A. Lakatos, S.T. Michell, L.L. Parker, G.J. Peresta, P.E. Nixon III, B. Savoy, S.M. Harris, R. MacDonald, H. Pros, and J. Martinez. 1993. Carbon Dioxide Enrichment: Data on the Response of Cotton to Varying $\mathrm{CO}_{2}$ Irrigation, and Nitrogen, ORNL/CDIAC-44, NDP-037 (R.J. Sepanski, editor). Oak Ridge National Laboratory, Oak Ridge, Tennessee.

Koertzinger, A., L. Mintrop, and J.C. Duinker. 1999. The International Intercomparison Exercise of Underway fCO2 Systems During the $R / V$ Meteor Cruise 36/1 in the North Atlantic Ocean, ORNL/CDIAC-114, NDP-067 (A. Kozyr, editor). Oak Ridge National Laboratory, Oak Ridge, Tennessee.

Lamb, H.H. 1985. Volcanic Loading: The Dust Veil Index, NDP-013. Oak Ridge National Laboratory, Oak Ridge, Tennessee.

Lamb, M.F., R.A. Feely, L. Moore, and D.K. Atwood. 1995. Total Carbon Dioxide, Hydrographic, and Nitrate Measurements in the Southwest Pacific During Austral Autumn, 1990: Results from NOAA/PMEL CGC-90 Cruise, ORNL/CDIAC-84, NDP-052 (A. Kozyr, editor). Oak Ridge National Laboratory, Oak Ridge, Tennessee. 
Larson, N.R., J.J. Michalsky, and B.A. LeBaron. 1996. Rattlesnake Mountain Observatory (46.4 $4^{\circ}$, 119.6 $6^{\circ}$ W) Multispectral Optical Depth Measurements: 1979-1994, ORNL/CDIAC-85, NDP-053 (R.C. Daniels, editor). Oak Ridge National Laboratory, Oak Ridge, Tennessee.

Leifer, R., and N. Chan. 1997. The Environmental Measurements Laboratory's Stratospheric Radionuclide (RANDAB) and Trace Gas (TRACDAB) Databases, DB1019 (T. A. Boden, editor). Oak Ridge National Laboratory, Oak Ridge, Tennessee.

Lewis, E., and D. Wallace. 1998. Program Developed for $\mathrm{CO}_{2}$ System Calculations, ORNL/CDIAC-105 (L.J. Allison, editor). Oak Ridge National Laboratory, Oak Ridge, Tennessee.

Li, Y.-F. 1996. Global Population Distribution (1990), Terrestrial Area and Country Name Information on a One by One Degree Grid Cell Basis, DB1016 (A.L. Brenkert, editor). Oak Ridge National Laboratory, Oak Ridge, Tennessee.

Luxmoore, R.J., R.J. Norby, E.G. O'Neill, D.G. Weller, J.M. Ells, and H.H. Rogers. 1985. Growth and Chemical Responses to CO 2 Enrichment - Virginia Pine (Pinus Virginiana Mill.), NDP-009. Oak Ridge National Laboratory, Oak Ridge, Tennessee.

Marland, G., T.A. Boden, and R.J. Andres. 2001. Global, Regional, and National Annual CO, Emissions from Fossil-Fuel Burning, Cement Production, and Gas Flaring: 1751-1998, ORNL/CDIAC-90, NDP-030. Oak Ridge National Laboratory, Oak Ridge, Tennessee.

McLaughlin, S.B., D.J. Downing, T.J. Blasing, B.L. Jackson, D.J. Pack, D.N. Duvick, L.K. Mann, and T.W. Doyle. 1994. FORAST Database, DB1005. Oak Ridge National Laboratory, Oak Ridge, Tennessee.

Millero, F.J., S. Fiol, D.M. Campbell, and G. Parrilla. 2000. Carbon Dioxide, Hydrographic, and Chemical Data Obtained During the R/V Hesperides Cruise in the Atlantic Ocean (WOCE Section A5, July 14 - August 15, 1992), ORNL/CDIAC-125, NDP-074 (L.J. Allison and A. Kozyr, editors). Oak Ridge National Laboratory, Oak Ridge, Tennessee.

Murphy, P.P., K.C. Kelly, R.A. Feely, and R.H. Gammon. 1995. Carbon Dioxide Concentrations in Surface Water and the Atmosphere During 1986-1989, NOAA/PMEL Cruises in the Pacific and Indian Oceans, ORNL/CDIAC-75, NDP-047 (A. Kozyr, editor). Oak Ridge National Laboratory, Oak Ridge, Tennessee.

National Climatic Data Center. 1989. Average Total Snowfall Data for Selected U.S. Stations, NDP-031. Oak Ridge National Laboratory, Oak Ridge, Tennessee.

Nelson, T.R., and T.A. Boden. 1991. CDIAC's Numeric Data Package Collection: Selected Data Sets Relevant to Studies of Greenhouse Gases and Climate (Prototype 1.01), CD-ROM. Oak Ridge National Laboratory, Oak Ridge, Tennessee.

Nelson, T.R., and T.A. Boden. 1993. CDIAC's Numeric Data Package Collection: Selected Data Sets Relevant to Studies of Greenhouse Gases and Climate (Version 1.02), ORNL/M-3107 (2-volume CD-ROM set). Oak Ridge National Laboratory, Oak Ridge, Tennessee.

Novelli, P.C., and K.A. Masarie. 1995. Atmospheric Carbon Monoxide Mixing Ratios - NOAA Climate Monitoring and Diagnostics Laboratory Cooperative Air Sampling Network, 1988-1993, DB1011. Oak Ridge National Laboratory, Oak Ridge, Tennessee.

Novelli, P., and K. Masarie. 1998. Measurement of Air Pollution from Satellites (MAPS) 1994 Correlative Atmospheric Carbon Monoxide Mixing Ratios, DB1020 (L.J. Allison and T.A. Boden, editors). Oak Ridge National Laboratory, Oak Ridge, Tennessee.

Nydal, R. 1998. Carbon-14 Measurements in Surface Water CO from the Atlantic, Indian, and Pacific Oceans, 1965-1994, ORNL/CDIAC-104, NDP-057A (A. Brenkert and T. Boden, editors). Oak Ridge National Laboratory, Oak Ridge, Tennessee.

Nydal, R., and K. Lövseth. 1996. Carbon-14 Measurements in Atmospheric CO from Northern and Southern Hemisphere Sites, 19621993, ORNL/CDIAC-93, NDP-057 (V. Zumbrunn and T.A. Boden, editors). Oak Ridge National Laboratory, Oak Ridge, Tennessee.

Östlund, H.G., and C. Grall. 1992. Indian Ocean Radiocarbon: Data from the INDIGO 1, 2, and 3 Cruises, ORNL/CDIAC-41, NDP-036 (R.J. Sepanski, editor). Oak Ridge National Laboratory, Oak Ridge, Tennessee.

Östlund, H.G., and M. Stuiver. 1988. GEOSECS Atlantic, Pacific, Indian, and Mediterranean Radiocarbon Data, NDP-027. Oak Ridge National Laboratory, Oak Ridge, Tennessee.

Olson, J.S., J.A. Watts, and L.J. Allison. 1985. Major World Ecosystem Complexes Ranked by Carbon in Live Vegetation: A Database, NDP-017. Oak Ridge National Laboratory, Oak Ridge, Tennessee. 
Patterson, R.K., L.A. Hook, M.-D. Cheng, and T.A. Boden. 1998. NARSTO Quality Systems Management Plan, ORNL/CDIAC-110. Oak Ridge National Laboratory, Oak Ridge, Tennessee.

Prell, W.L. 1986. A Global Planktonic Foraminifera Data Base for Evaluation of the Stability of Low-Latitude Sea Surface Temperatures, NDP-024. Oak Ridge National Laboratory, Oak Ridge, Tennessee.

Prinn, R., D. Cunnold, P. Fraser, R. Weiss, P. Simmonds, F. Alyea, L.P. Steele, D. Hartley, and R.H.J. Wang. 2001. The $A L E / G A G E / A G A G E$ Network, DB1001 (T.A. Boden, editor). Oak Ridge National Laboratory, Oak Ridge, Tennessee.

Quay, P., and J. Stutsman. 1999. Measurements of Atmospheric Methane and ${ }^{13} \mathrm{C}^{12} \mathrm{C}$ of Atmospheric Methane from Flask Air Samples, . Oak Ridge National Laboratory.

Raich, J.W., and C.S. Potter. 1996. Global Patterns of Carbon Dioxide Emissions from Soils on a 0.5 Degree Grid Cell Basis, DB1015 (A.L. Brenkert, editor). Oak Ridge National Laboratory, Oak Ridge, Tennessee.

Razuvaev, V.N., E.G. Apasova, and R.A. Martuganov. 1993. Daily Temperature and Precipitation Data for 223 U.S.S.R. Stations, ORNL/CDIAC-56, NDP-040 (R.S. Vose, editor). Oak Ridge National Laboratory, Oak Ridge, Tennessee.

Razuvayev, V.N., E.G. Apasova, and R.A. Martuganov. 1998. Six- and Three-Hourly Meteorological Observations from 233 U.S.S.R. Stations, ORNL/CDIAC-108, NDP-048 (D.P. Kaiser, editor). Oak Ridge National Laboratory, Oak Ridge, Tennessee.

Richards, J.F., and E.P. Flint. 1995. Historic Land Use and Carbon Estimates for South and Southeast Asia: 1880-1980, ORNL/CDIAC61, NDP-046 (R.C. Daniels, editor). Oak Ridge National Laboratory, Oak Ridge, Tennessee.

Riggs, J.S., M.L. Tharp, and R.J. Norby. 2001. ORNL FACE Weather Data, http://cdiac.esd.ornl.gov/programs/FACE/ornldata/weatherfiles.htm. Oak Ridge National Laboratory.

Robock, A., I.I. Borzenkova, G.V. Gruza, and K.Y. Vinnikov. 1988. Surface-Air-Temperature Anomalies for the Northern Hemisphere: The Russian Data Set, NDP-015. Oak Ridge National Laboratory, Oak Ridge, Tennessee.

Rotty, R.M., and G. Marland. 1984. Production of $\mathrm{CO}_{2}$ from Fossil Fuel Burning by Fuel Type, 1860-1982, NDP-006. Oak Ridge National Laboratory, Oak Ridge, Tennessee.

Rubin, S., J.G. Goddard, D.W. Chipman, T. Takahashi, S.C. Sutherland, J.L. Reid, J.H. Swift, and L.D. Talley. 1998. Carbon Dioxide, Hydrographic, and Chemical Data Obtained in the South Pacific Ocean (WOCE Section P16A/P17A, P17E/P19S, and P19C, R/V Knorr, October 1992-April 1993), ORNL/CDIAC-109, NDP-065 (A. Kozyr, editor). Oak Ridge National Laboratory, Oak Ridge, Tennessee.

Sabine, C.L., and R.M. Key. 1997. Surface Water and Atmospheric Underway Carbon Data Obtained During the World Ocean Circulation Experiment Indian Ocean Survey Cruises (R/V Knorr, December 1994-January 1996), ORNL/CDIAC-103, NDP-064 (A. Kozyr and L. Allison, editors). Oak Ridge National Laboratory, Oak Ridge, Tennessee.

Sabine, C.L., R.M. Key, and M. Hall. 1999. Carbon Dioxide, Hydrographic, and Chemical Data Obtained During the R/V Thomas G. Thompson Cruise in the Pacific Ocean (WOCE Section P10, October 5 - November 10, 1993), ORNL/CDIAC-122, NDP-071 (A. Kozyr, editor). Oak Ridge National Laboratory, Oak Ridge, Tennessee.

Steele, L.P., and P.M. Lang. 1991. Atmospheric Methane Concentrations - The NOAA/CMDL Global Cooperative Flask Sampling Network, 1983-1988, NDP-038. Oak Ridge National Laboratory, Oak Ridge, Tennessee.

Steurer, P.M., and T.R. Karl. 1991. Historical Sunshine and Cloud Data in the United States, NDP-021. Oak Ridge National Laboratory, Oak Ridge, Tennessee.

Stevens, C.M. 1996. Carbon-13 Isotopic Abundance and Concentration of Atmospheric Methane for Background Air in the Southern and Northern Hemispheres from 1978 to 1989, ORNL/CDIAC-80, NDP-049 (R.J. Sepanski, and L.J. Morris, editors). Oak Ridge National Laboratory, Oak Ridge, Tennessee.

Suchet, P.A., and J.-L. Probst. 1995. A Global 1 Degree by 1 Degree Distribution of Atmospheric/Soil CO 2 Consumption by Continental Weathering and of Riverine $\mathrm{HCO}_{3}$ Yield, DB1012. Oak Ridge National Laboratory, Oak Ridge, Tennessee.

Takahashi, T., G. Goddard, S. Rubin, D.W. Chipman, S.C. Sutherland, and C. Goyet. 1996. Carbon Dioxide, Hydrographic, and Chemical Data Obtained in the Central South Pacific Ocean (WOCE Sections P17S and P16S) During the TUNES-2 Expedition of the R/V Thomas 
Washington, July-August 1991, ORNL/CDIAC-86, NDP-054 (A. Kozyr, editor). Oak Ridge National Laboratory, Oak Ridge, Tennessee.

Tao, S., C. Fu, Z. Zeng, and Q. Zhang. 1997. Two Long-Term Instrumental Climatic Data Bases of the People's Republic of China, ORNL/CDIAC-47, NDP-039 (D.P. Kaiser, editor). Oak Ridge National Laboratory, Oak Ridge, Tennessee.

Trivett, N.B.A., V.C. Hudec, and C.S. Wong. 1995. Atmospheric CO 2 Concentrations - The Canadian Background Air Pollution Monitoring Network, NDP-034. Oak Ridge National Laboratory, Oak Ridge, Tennessee.

Vose, R.S., R.L. Schmoyer, P.M. Steurer, T.C. Peterson, R. Heim, T.R. Karl, and J.K. Eischeid. 1992. The Global Historical Climatology Network; Long-Term Monthly Temperature, Precipitation, Sea Level Pressure, and Station Pressure Data, ORNL/CDIAC-53, NDP-041. Oak Ridge National Laboratory, Oak Ridge, Tennessee.

Webb, T., III. 1985. Global Paleoclimatic Data for 6000 B.P, NDP-011. Oak Ridge National Laboratory, Oak Ridge, Tenessee.

Weiss, R.F., F.A. Van Woy, and P.K. Salameh. 1993. Surface Water and Atmospheric Carbon Dioxide and Nitrous Oxide Observations by Shipboard Automated Gas Chromatography: Results from Expeditions Between 1977 and 1990, ORNL/CDIAC-59, NDP-044 (R.J. Sepanski, editor). Oak Ridge National Laboratory, Oak Ridge, Tennessee.

Zinke, P.J., A.G. Stangenberger, W.M. Post, W.R. Emanuel, and J.S. Olson. 1986. Worldwide Organic Soil Carbon and Nitrogen Data, NDP-018. Oak Ridge National Laboratory, Oak Ridge, Tennessee.

\section{Other ORNL and DOE Reports}

Allison, L.J. 1984. User's Guide to the Carbon Dioxide Information Center's Bibliographic Information System, ORNL/CDIC-7. Oak Ridge National Laboratory, Oak Ridge, Tennessee.

Allison, L.J., C.T. Hunsaker, R.M. Cushman, T.W. White, and J.D. Draves. 1990. Environmental Atlas of the Iowa-Kansas-MissouriNebraska Climate-Change Study Region, ORNL/CDIAC-33. Oak Ridge National Laboratory, Oak Ridge, Tennessee.

Allison, L.J., and H.A. Pfuderer. 1983. Guide to the Bibliographic Format Used by the Carbon Dioxide Information Center, ORNL/CDIC6. Oak Ridge National Laboratory, Oak Ridge, Tennessee.

Boden, T.A., D.P. Kaiser, R.J. Sepanski, and F.W. Stoss. 1994. Trends '93: A Compendium of Data on Global Change, ORNL/CDIAC-65. Oak Ridge National Laboratory, Oak Ridge, Tennessee.

Boden, T.A., P. Kanciruk, and M.P. Farrell. 1991. Trends '90: A Compendium of Data on Global Change, ORNL/CDIAC-36. Oak Ridge National Laboratory, Oak Ridge, Tennessee.

Boden, T.A., F.M. O'Hara Jr., and F.W. Stoss. 1993. CDIAC Catalog - Numeric Data Packages and Computer Model Packages, ORNL/CDIAC-64. Oak Ridge National Laboratory, Oak Ridge, Tennessee.

Boden, T.A., R.J. Sepanski, and F.W. Stoss. 1991. Trends '91: A Compendium of Data on Global Change, ORNL/CDIAC-46. Oak Ridge National Laboratory, Oak Ridge, Tennessee.

Boden, T.A., R.J. Sepanski, and F.W. Stoss. 1992. Trends '91: A Compendium of Data on Global Change - Highlights, ORNL/CDIAC-49. Oak Ridge National Laboratory, Oak Ridge, Tennessee.

Burtis, M.D. 1999. Catalog of Databases and Reports, ORNL/CDIAC-34. Oak Ridge National Laboratory, Oak Ridge, Tennessee.

Carbon Dioxide Information Analysis Center. 2001. Trends Online, http://cdiac.esd.ornl.gov/trends/trends.htm. Oak Ridge National Laboratory, Oak Ridge, Tennessee.

Chang, L.H., J.D. Draves, and C.T. Hunsaker. 1992. Climate Change and Water Supply, Management and Use: Literature Review, ORNL/CDIAC-52. Oak Ridge National Laboratory, Oak Ridge, Tennessee.

Cushman, R.M. 2001. Publications, Presentations, and Awards, ORNL/CDIAC-101. Oak Ridge National Laboratory, Oak Ridge, Tennessee.

Cushman, R.M., T.A. Boden, L.A. Hook, S.B. Jones, D.P. Kaiser, A. Kozyr, and T.R. Nelson. 2001. Carbon Dioxide Information Analysis 
Center and World Data Center for Atmospheric Trace Gases Fiscal Year 2000 Annual Report, ORNL/CDIAC-133. Oak Ridge National Laboratory, Oak Ridge, Tennessee.

Cushman, R.M., T.A. Boden, L.A. Hook, S.B. Jones, D.P. Kaiser, and T.R. Nelson. 1999. Fiscal Year 1998 Annual Report, ORNL/CDIAC-116. Oak Ridge National Laboratory, Oak Ridge, Tennessee.

Cushman, R.M., T.A. Boden, S.B. Jones, D.P. Kaiser, and T.R. Nelson. 1997. Carbon Dioxide Information Analysis Center and World Data Center-A for Atmospheric Trace Gases: Fiscal Year 1996 Annual Report, ORNL/CDIAC-98. Oak Ridge National Laboratory, Oak Ridge, Tennessee.

Cushman, R.M., T.A. Boden, S.B. Jones, D.P. Kaiser, and T.R. Nelson. 1998. Carbon Dioxide Information Analysis Center and World Data Center-A for Atmospheric Trace Gases: Fiscal Year 1997 Annual Report, ORNL/CDIAC-106. Oak Ridge National Laboratory, Oak Ridge, Tennessee.

Cushman, R.M., T.A. Boden, S.B. Jones, T.R. Nelson, and F.W. Stoss. 1995. Carbon Dioxide Information Analysis Center and World Data Center-A for Atmospheric Trace Gases: Annual Progress Report, Fiscal Year 1994, ORNL/CDIAC-76. Oak Ridge National Laboratory, Oak Ridge, Tennessee.

Cushman, R.M., T.A. Boden, S.B. Jones, T.R. Nelson, and F.W. Stoss. 1996. Carbon Dioxide Information Analysis Center and World Data Center-A for Atmospheric Trace Gases: Fiscal Year 1995 Annual Report, ORNL/CDIAC-89. Oak Ridge National Laboratory, Oak Ridge, Tennessee.

Cushman, R.M., A. Harrison, and K. Stevens. 2000. Graduate Student Theses Supported by DOE's Environmental Sciences Division: Fiscal Year 2000 Update, ORNL/CDIAC-130. Oak Ridge National Laboratory, Oak Ridge, Tennessee.

Cushman, R.M., and B.M. Parra. 1995. Graduate Student Theses Supported by DOE's Environmental Sciences Division, DOE/ER-0649T. U.S. Department of Energy, Washington, D.C.

Cushman, R.M., and F.W. Stoss. 1992. Carbon Dioxide Information Analysis Center: FY 1991 Activities, ORNL/CDIAC-48. Oak Ridge National Laboratory, Oak Ridge, Tennessee.

Cushman, R.M., and F.W. Stoss. 1993. Carbon Dioxide Information Analysis Center and World Data Center-A for Atmospheric Trace Gases: FY 1993 Activities, ORNL/CDIAC-67. Oak Ridge National Laboratory, Oak Ridge, Tennessee.

Cushman, R.M., and F.W. Stoss. 1993. Carbon Dioxide Information Analysis Center: FY 1992 Activities, ORNL/CDIAC-58. Oak Ridge National Laboratory, Oak Ridge, Tennessee.

Cushman, R.M., J.C. Waterhouse, and M.P. Farrell. 1989. Environmental Consequences of $\mathrm{CO}_{2}$-Climate Interactions: The Need for Integrated Resource Analysis, ORNL/CDIAC-28. Oak Ridge National Laboratory, Oak Ridge, Tennessee.

Daniels, R.C., V.M. Gornitz, A.J. Mehta, S.-C. Lee, and R.M. Cushman. 1992. Adapting to Sea-Level Rise in the U.S. Southeast: The Influence of Built Infrastructure and Biophysical Factors on the Inundation of Coastal Areas, ORNL/CDIAC-54. Oak Ridge National Laboratory, Oak Ridge, Tennessee.

Dickson, A.G., and C. Goyet. 1994. Handbook of Methods for the Analysis of the Various Parameters of the Carbon Dioxide System in Sea Water, ORNL/CDIAC-74. Oak Ridge National Laboratory, Oak Ridge, Tennessee.

Farrell, M.P. 1985. Carbon Dioxide Information Center FY 1985 Progress Report, ORNL/CDIC-11. Oak Ridge National Laboratory, Oak Ridge, Tennessee.

Farrell, M.P. 1987. Master Index for the Carbon Dioxide Research State-of-the-Art Report Series, DOE/ER-0316. U.S. Department of Energy, Washington, D.C.

Feely, R., M. Lamb, D. Greeley, and R. Wanninkhof. 1999. Comparison of the Carbon System Parameters at the Global CO2 Survey Crossover Locations in the North and South Pacific Ocean, 1990-1996, ORNL/CDIAC-115. Oak Ridge National Laboratory, Oak Ridge, Tennessee.

Fulkerson, W., R.M. Cushman, G. Marland, and S. Rayner. 1989. International Impacts of Global Climate Change: Testimony to House Appropriations Subcommittee on Foreign Operations, Export Financing and Related Programs, ORNL/TM-11184. Oak Ridge National Laboratory, Oak Ridge, Tennessee. 
Ge, Q.S., P.Y. Zhang, X.P. Liu, X.Q. Zhang, Y. Chen, G.T. Peng, and J.Y. Zheng. 1999. Selected Translated Abstracts of ChineseLanguage Climate Change Publications, ORNL/CDIAC-117, W.-C. Wang, R.M. Cushman, and M.D. Burtis, compilers.

Hattemer-Frey, H.A., T.R. Karl, and F.T. Quinlan. 1986. An Annotated Inventory of Climatic Indices and Data Sets, TR035, DOE/NBB0080. U.S. Department of Energy, Washington, D.C.

Jacobs, B.F., and N.E. Sevier. 1985. User's Guide for the Carbon Dioxide Information Center's World Directory of Research and Policymakers, ORNL/CDIC-9. Oak Ridge National Laboratory, Oak Ridge, Tennessee.

Jones, M.H., and P.S. Curtis. 2000. Bibliography on CO2 Effects on Vegetation and Ecosystems: 1990-1999 Literature, ORNL/CDIAC129. Oak Ridge National Laboratory, Oak Ridge, Tennessee.

Kaiser, D., S. Tao, C. Fu, Z. Zeng, Q. Zhang, W.-C. Wang, and T. Karl. 1993. Climate Data Bases of the People's Republic of China 18411988, TR055, DOE/NBB-0091T. U.S. Department of Energy, Washington, D.C.

Mehta, A.J., and R.M. Cushman. 1989. Workshop on Sea Level Rise and Coastal Processes, DOE/NBB-0086. U.S. Department of Energy, Washington, D.C.

Millemann, R.E. 1986. Carbon Dioxide Information Center Thesaurus, ORNL/CDIC-5. Oak Ridge National Laboratory, Oak Ridge, Tennessee.

Millemann, R.E. 1987. Graduate Student Theses Supported by Carbon Dioxide Research Division Office of Basic Energy Sciences, U.S. Department of Energy, ORNL/CDIAC-21. Oak Ridge National Laboratory, Oak Ridge, Tennessee.

Millemann, R.E. 1988. A Glossary for Carbon Dioxide and Climate, ORNL/CDIC-22. Oak Ridge National Laboratory, Oak Ridge, Tennessee.

Millemann, R.E., and R.M. Cushman. 1986. Subject Keywords Index for the Carbon Dioxide Information Center's Bibliographic Information System, ORNL/CDIC-15. Oak Ridge National Laboratory, Oak Ridge, Tennessee.

Miller, D.B., and R.M. Cushman. 1989. Preliminary Development of a Seashore-Effects Analysis System, ORNL/CDIAC-23. Oak Ridge National Laboratory, Oak Ridge, Tennessee.

O'Hara, F.M., Jr. 1990. Glossary: Carbon Dioxide and Climate, ORNL/CDIAC-39. Oak Ridge National Laboratory, Oak Ridge, Tennessee.

Peterson, T.C. 1993. Report of the International Workshop on Quality Control of Monthly Climate Data, ORNL/CDIAC-69, NCDC Global Climate Laboratory Monograph. Oak Ridge National Laboratory, Oak Ridge, Tennessee.

Ravina, C.B., and M.D. Burtis. 1992. Selected Translated Abstracts of Russian-Language Climate-Change Publications. I. Surface Energy Budget, ORNL/CDIAC-57, Proceedings of RIHMI-WDC, Issue 158. Oak Ridge National Laboratory, Oak Ridge, Tennessee.

Ravina, C.B., and M.D. Burtis. 1994. Selected Translated Abstracts of Russian-Language Climate-Change Publications. II. Clouds, ORNL/CDIAC-64, Proceedings of RIHMI-WDC, Issue 159. Oak Ridge National Laboratory, Oak Ridge, Tennessee.

Razuvaev, V.N., and S.G. Sivachok. 1995. Selected Translated Abstracts of Russian-Language Climate-Change Publications. III. Aerosols, ORNL/CDIAC-88, Proceedings of RIHMI-WDC, Issue 164. Oak Ridge National Laboratory, Oak Ridge, Tennessee.

Razuvaev, V.N., and S.G. Sivachok. 1996. Selected Translated Abstracts of Russian-Language Climate-Change Publications. IV. General Circulation Models, ORNL/CDIAC-94, Proceedings of RIHMI-WDC, Issue 165. Oak Ridge National Laboratory, Oak Ridge, Tennessee.

Strain, B.R., and J.D. Cure. 1986. Direct Effects of Atmospheric CO Enrichment on Plants and Ecosystems: A Bibliography with Abstracts, ORNL/CDIC-13. Oak Ridge National Laboratory, Oak Ridge, Tennessee.

Strain, B.R., and J.D. Cure. 1994. Direct Effects of Atmospheric $\mathrm{CO}_{2}$ Enrichment on Plants and Ecosystems: An Updated Bibliographic Data Base. Oak Ridge National Laboratory, Oak Ridge, Tennessee.

Watts, J.A. 1985. Carbon Dioxide and Climate: A Working Glossary, ORNL/CDIC-10. Oak Ridge National Laboratory, Oak Ridge, Tennessee. 
Watts, J.A., and L.J. Allison. 1983. An Inventory of Numeric Data for Carbon Dioxide Research, ORNL/CDIC-1. Oak Ridge National Laboratory, Oak Ridge, Tennessee.

Woodard, C.T., and F.W. Stoss. 1995. Global Change Acronyms and Abbreviations, ORNL/CDIAC-83. Oak Ridge National Laboratory, Oak Ridge, Tennessee.

\section{Presentations}

Andres, R.J., G. Marland, T. Boden, and S. Bischof. 1993. Carbon Dioxide Emissions from Fossil Fuel Combustion and Cement Manufacture 1751-1991; And an Estimate of their Isotopic Composition and Latitudinal Distribution, PRESENTED AT Global Change Institute, Snowmass, Colorado.

Boden, T.A. 1992. Metadata Compiled and Distributed by the Carbon Dioxide Information Analysis Center for Global Climate Change and Greenhouse Gas-Related Data Bases, PRESENTED AT Scientific Data Management Workshop, Salt Lake City, Utah.

Boden, T.A. 1993. Experiences and Lessons Learned Providing Data from the Carbon Dioxide Information Analysis Center, PRESENTED AT NEXRAD WSR-88D Workshop, Norman, Oklahoma.

Boden, T.A. 1994. Archival, Distribution, and Advertisement Activities, PRESENTED AT Ninth AGAGE Meeting, Hilton Head Island, South Carolina.

Boden, T.A. 1995. The Carbon Dioxide Information Analysis Center's Ocean-Related Data Management Activities, PRESENTED AT Intergovernmental Oceanographic Commission Data Subpanel Meeting on $\mathrm{pCO}_{2}$, Paris, France.

Boden, T.A. 1995. CDIAC Data Activities, PRESENTED AT $\mathrm{WMO} \mathrm{CO}_{2}$ Expert Meeting, Boulder, Colorado.

Boden, T.A. 1996. Global, Regional, and National Carbon Dioxide Emissions from Fossil-Fuel Consumption and Cement Production with Special Emphasis on Chinese Emissions, PRESENTED AT Invited Lecture, Tianjin, China.

Boden, T.A. 1996. Oceanographic Data Activities of the Carbon Dioxide Information Analysis Center and World Data Center-A for Atmospheric Trace Gases, PRESENTED AT Invited Lecture, Tianjin, China.

Boden, T.A. 1996. Status Report on CDIAC Data Management Activities in Support of the DOE Ocean CO 2 Survey, PRESENTED AT Thirteenth DOE $\mathrm{CO}_{2}$ Survey Science Team Meeting, Gaithersburg, Maryland.

Boden, T.A. 1996. Trends in Atmospheric Trace Gases and Related Species, PRESENTED AT Montana Consortium Lecture Series, Oak Ridge, Tennessee.

Boden, T.A. 1997. Data and Information Activities by the Carbon Dioxide Information Analysis Center (CDIAC) in Support of the CO 2 Experts Group, PRESENTED AT Ninth $\mathrm{WMO} \mathrm{CO}_{2}$ and Isotopic Measurement Experts Meeting, Aspendale, Australia.

Boden, T.A. 1998. Data Activities at CDIAC and the WDC-A for Atmospheric Trace Gases, PRESENTED AT Third GAW World Data Center Managers Meeting, Kjeller, Norway.

Boden, T.A., and R.M. Cushman. 1995. Data Activities of the Carbon Dioxide Information Analysis Center and World Data Center-A for Atmospheric Trace Gases, PRESENTED AT Data Center Directors Meeting, Asheville, North Carolina.

Boden, T.A., D.P. Kaiser, R.J. Sepanski, L.J. Morris, D.E. Shepherd, and S.B. Jones. 1993. Data Archival, Documentation, and Distribution Activities Performed by the Carbon Dioxide Information Analysis Center, PRESENTED AT PRC/CAS - US/DOE Sixth Science Team Meeting, Joint Research on the Greenhouse Effect, Beijing, China.

Boden, T.A., and P. Kanciruk. 1996. Advancing Technology and Data Center Operations, PRESENTED AT All World Data Center Conference, Wageningen, The Netherlands.

Boden, T.A., G. Marland, and R.J. Andres. 1996. $\mathrm{CO}_{2}$ Emission Calculations and Trends, PRESENTED AT 1995 Symposium on Greenhouse Gas Emissions and Mitigation Research, Washington, D.C.

Boden, T.A., G. Marland, and A.L. Brenkert. 1997. Magnitude and Distribution of $\mathrm{CO}_{2}$ Emissions from Fossil-Fuel Burning, Cement 
Production, and Gas Flaring: 1950-1994, PRESENTED AT Conference on Global Measurements of Atmospheric Chemistry, Toronto, Canada.

Boden, T.A., G. Marland, A. Brenkert, R.J. Andres, and J.G.J. Olivier. 1997. $\mathrm{CO}_{2}$ from Fossil Fuel Burning: Updates on the Magnitude, Distribution, and Uncertainty of Emissions Estimates, PRESENTED AT Fifth International Carbon Dioxide Conference, Cairns, Australia.

Brenkert, A.L. 1996. Introducing CDIAC to the AmeriFlux Network, PRESENTED AT AmeriFlux Network Conference, St. Louis, Missouri.

Brenkert, A.L., G. Marland, and J. Olivier. 1997. $\mathrm{CO}_{2}$ Emissions from Fossil-Fuel Burning: Comparisons of 1990 Gridded Maps and an Update to 1995 (poster), PRESENTED AT Fall Meeting, American Geophysical Union, San Francisco.

Cushman, R.M. 1989. The Greenhouse Effect, PRESENTED AT Western Regional Biomass Energy Program, Agricultural Resource Group Meeting, Lakewood, Colorado.

Cushman, R.M. 1991. Using Climate Model Output to Assess the Impacts of Climate Change on Water Resources, PRESENTED AT Water Resources: Planning and Management and Urban Water Resources, New Orleans, Louisiana.

Cushman, R.M. 1993. Retrospective of CDIAC Activities, PRESENTED AT Eighteenth Annual Meeting, Working Group VIII, Asheville, North Carolina.

Cushman, R.M. 1994. The Origins of Greenhouse Gases - The Need and Possibilities for Abatement, PRESENTED AT GREENTIE GLG Meeting, Maastricht, The Netherlands.

Cushman, R.M. 1995. Greenhouse Gases: Sources and Mitigation, PRESENTED AT Plant \& Soil Science 432, The University of Tennessee, Knoxville, Tennessee.

Cushman, R.M. 1996. The Carbon Dioxide Information Analysis Center, PRESENTED AT NIGEC Interregional Climate Change Conference, Tuscaloosa, Alabama.

Cushman, R.M. 1996. Data Support for Integrated Assessment Research, PRESENTED AT Energy Modeling Forum, Snowmass, Colorado.

Cushman, R.M. 1996. Establishing Priorities for Reducing Greenhouse-Gas Emissions, PRESENTED AT Eighty-Ninth Annual Meeting and Exhibition, Air and Waste Management Association, Nashville, Tennessee.

Cushman, R.M. 1996. Global Change Data at ORNL: It's Not Just $\mathrm{CO}_{2}$ Anymore, PRESENTED AT A Forum for Integrating Multidisciplinary Research to Advance the Science of Global Change, Oak Ridge, Tennessee.

Cushman, R.M. 1996. The Role of CDIAC in Data Management for FACE, PRESENTED AT FACE Science Meeting, Durham, North Carolina.

Cushman, R.M. 1998. CDIAC: Data and Information for Global-Change Studies, PRESENTED AT Special Libraries Association 89th Annual Conference, Indianapolis.

Cushman, R.M. 1998. CDIAC's Recent Working Group VIII Activities, PRESENTED AT Working Group VIII Meeting, Boulder, Colorado.

Cushman, R.M. 1999. Data and Information Management for Free-Air $\mathrm{CO}_{2}$ Enrichment (FACE), PRESENTED AT USDA/ARS Global Change National Program Workshop, Denver, Colorado.

Cushman, R.M. 2000. All The Greenhouse Gases: Where Do They All Come From?, PRESENTED AT DOE Global Change Education Program End-of-Summer Workshop, Oak Ridge, Tennessee.

Cushman, R.M. 2000. Data and Information Management for FACE (poster), PRESENTED AT FACE 2000 International Conference, Tsukuba, Japan.

Cushman, R.M., J.J. Beauchamp, and A.L. Brenkert. 1998. Validating CDIAC's Population-Based Approach to the Disaggregation of Within-Country $\mathrm{CO}_{2}$ Emissions, PRESENTED AT Global Climate Change: Science, Policy, and Mitigation/Adaptation Strategies, 
Washington, D.C.

Cushman, R.M., T.A. Boden, M.P. Farrell, S.B. Jones, D.P. Kaiser, P. Kanciruk, E.E. Mitchell, T.R. Nelson, and R.J. Sepanski. 1999. Retrospective on CDIAC's Activities in United States-China Research on the Greenhouse Effect, PRESENTED AT Tenth Science Team Meeting of the U.S. Department of Energy and the Chinese Academy of Sciences Joint Research on the Greenhouse Effect, Beijing.

Cushman, R.M., M.P. Farrell, and F.A. Koomanoff. 1986. Climate predictions and regional resource analysis, PRESENTED AT Eleventh General Assembly, European Geophysical Society, Kiel, Federal Republic of Germany.

Cushman, R.M., D.B. Hunsaker Jr., M.S. Salk, and R.M. Reed. 1989. Global Climate Change and NEPA Analyses, PRESENTED AT The Scientific Challenges of NEPA: Future Directions Based on 20 Years of Experience, Knoxville, Tennessee.

Cushman, R.M., and S.B. Jones. 1997. The Carbon Dioxide Information Analysis Center and World Data Center-A for Atmospheric Trace Gases (poster), PRESENTED AT Kyoto and Beyond: International Climate Change Policy Moves to Center Stage, Washington, D.C.

Cushman, R.M., S.B. Jones, and F.W. Stoss. 1995. Promotion and Outreach at CDIAC, PRESENTED AT GCDIS Data Centers Workshop, Oak Ridge, Tennessee.

Cushman, R.M., and P. Kanciruk. 1993. The Role of CDIAC in Providing Information for the Global Climate-Change Issue (Workshop on Data Management for Global Environmental Studies, Yokohama, Japan), PRESENTED AT Workshop on Data Management for Global Environmental Studies, Yokohama, Japan.

Cushman, R.M., A. Kozyr, and F.M. Hoffman. 2000. CDIAC: Providing Global-Change Data and Information (poster), PRESENTED AT 2000 Oceans Sciences Meeting, San Antonio, Texas.

Cushman, R.M., J.C. Waterhouse, and M.P. Farrell. 1986. Bridging the Gap: Regional Definition, PRESENTED AT Carbon Dioxide Research State-of-the-Art Seminar, Washington, D.C.

Cushman, R.M., J.C. Waterhouse, and M.P. Farrell. 1986. Climate predictions, regions, and resources, PRESENTED AT Fifth US-USSR Symposium on Comprehensive Analysis of the Environment, Washington, D.C.

Daniels, R.C. 1994. Areas at Risk to Sea-Level Rise: Identification and Modeling the Impacts, PRESENTED AT Integrated Assessment of the Impact of Climate Change on the Caribbean Coastal Zone, Mayagüez, Puerto Rico.

Daniels, R.C., and T.W. Beaty. 1995. Identification of Coastlines at Risk to Sea-Level Rise Using the Coastal Hazards Data Base, PRESENTED AT Ninety-First Annual Meeting, Association of American Geographers, Chicago, Illinois.

Daniels, R.C., T.W. Beaty, and V.M. Gornitz. 1995. A Hazards Database for Long-Term Coastal Zone Management: A Gulf Coast Example (poster), PRESENTED AT Fifteenth Annual Environmental Systems Research Institute User Conference, Palm Springs, California.

Daniels, R.C., T.W. Beaty, and V.M. Gornitz. 1996. A Physical and Socioeconomic Index of Coastal Vulnerability (poster), PRESENTED AT Ninety-Second Annual Meeting, Association of American Geographers, Charlotte, North Carolina.

Daniels, R.C., E.P. Flint, and J.F. Richards. 1994. Deforestation and Carbon Estimates for South and Southeast Asia: 1880-1980, PRESENTED AT Ninetieth Annual Meeting, Association of American Geographers, San Francisco, California.

Feely, R.A., C.L. Sabine, K. Lee, F.J. Millero, M.F. Lamb, J.L. Bullister, R.M. Key, R. Wanninkhof, T.-H. Peng, and A. Kozyr. 2001. Organic Carbon Remineralization and Calcium Dissolution in the North Pacific Ocean, PRESENTED AT Biennal Scientific Meeting of The Oceanography Society, Miami Beach, Florida.

Feely, R.A., C.L. Sabine, R. Wanninkhof, R.M. Key, G.C. Johnson, F.J. Millero, K. Lee, T. Peng, J.L. Bullister, A. Kozyr, and M.F. Lamb. 2000. Synthesis of Global Ocean $\mathrm{CO}_{2}$ Survey Data, PRESENTED AT American Geophysical Union, Fall Meeting, San Francisco.

Jones, S., L.J. Morris, D.E. Shepherd, and T.W. Stamm. 1993. CDIAC's PC-Based Information Management System, PRESENTED AT Tenth Office Information Technology Conference, Knoxville, Tennessee.

Kaiser, D.P. 1993. Cloud Amount and Sunshine Duration in the People's Republic of China, 1954-88 (poster), PRESENTED AT Eighth Conference on Applied Climatology, Anaheim, California. 
Kaiser, D.P. 1995. Quality Assurance, Documentation, Analysis, and Archival of Historical Climate Databases by the Carbon Dioxide Information Analysis Center, PRESENTED AT First Chinese Meteorological Administration/U.S. Department of Energy Science Team Meeting, San Francisco, California.

Kaiser, D.P. 1995. Variation in Cloud Amount and Sunshine Duration over the PRC, 1954-1988, PRESENTED AT Seventh Meeting on Collaborative Research Between the People's Republic of China Academia Sinica and the U.S. Department of Energy on CO ${ }_{2}$-Induced Climate Change, San Francisco, California.

Kaiser, D.P. 1996. Changes in Monthly Mean Cloud Amount over China: A Closer Look, PRESENTED AT Eighth Meeting on Collaborative Research Between the People's Republic of China Academia Sinica and the U.S. Department of Energy on CO ${ }_{2}$ Induced Climate Change; Second Chinese Meteorological Administration/U.S. Department of Energy Science Team Meeting, Beijing, China.

Kaiser, D.P. 1997. Analysis of Monthly Mean Cloud Amount and Sunshine Duration for China: An Update Through 1993, PRESENTED AT Ninth Science Team Meeting, US DOE-Chinese Academy of Sciences Joint Study on the Greenhouse Effect, Seattle, Washington.

Kaiser, D.P. 1997. Analysis of Monthly Mean Cloud Amount for China: 1951-1994, PRESENTED AT Third Meeting, US DOE-China Meteorological Administration Agreement on the Joint Study of Regional Climate, Seattle, Washington.

Kaiser, D.P. 1998. Analysis of Monthly Mean Cloud Amount for China: 1951-1994, PRESENTED AT Ninth Symposium on Global Change Studies, Phoenix.

Kaiser, D.P. 2000. Decreasing Cloudiness Over China: An Updated Analysis Examining Additional Variables, PRESENTED AT Eightieth Annual Meeting, American Meteorological Society, Long Beach, California.

Kaiser, D.P. 2001. Assessing Observed Temperature and Cloud Amount Trends for China over the Last Half of the Twentieth Century: What Can the Sunshine Duration Record Tell Us?, PRESENTED AT Eighty-First Annual Meeting of the American Meteorological Society, Twelfth Symposium on Global Change and Climate Variations, Albuquerque, New Mexico.

Kaiser, D.P. 2001. Assessing observed temperature and cloud amount trends for China over the last half of the twentieth century: What can the sunshine duration record tell us?, PRESENTED AT Science Team Meeting of the United States and Peoples' Republic of China Joint Agreement on Global and Regional Climate Change, Washington, DC.

Kaiser, D.P., and V.N. Razuvaev. 1995. Cloud Cover and Type over the Former USSR, 1936-83: Trends Derived from the RIHMI-WDC 223-Station 6- and 3-Hourly Meteorological Database, PRESENTED AT Sixth International Meeting on Statistical Climatology, Galway, Ireland.

Kaiser, D.P., and R.S. Vose. 1994. Climatic variability in eastern China during the twentieth century, PRESENTED AT Ninetieth Annual Meeting, Association of American Geographers, San Francisco, California.

Kaiser, D.P., R.S. Vose, T.R. Karl, and V.N. Razuvaev. 1995. The Distribution of Cloud Cover over the Former USSR as Derived from the RIHMI 223-Station 3-Hourly Meteorological Climatology Database, PRESENTED AT Ninth Conference on Applied Climatology, Dallas, Texas.

Kozyr, A. 1998. CDIAC's Ocean $\mathrm{CO}_{2}$ Data Holdings and Status, PRESENTED AT $15^{\text {th }}$ DOE $\mathrm{CO}_{2}$ Survey Science Team Meeting, Miami, Florida.

Kozyr, A. 1998. Data Management Support Provided by the Carbon Dioxide Information Analysis Center for the U.S. DOE Ocean CO 2 Survey During WOCE Cruises, PRESENTED AT Ocean Circulation \& Climate, World Ocean Circulation Experiment Conference, Halifax, Canada.

Kozyr, A. 2000. Data Management Support Provided by the Carbon Dioxide Information Analysis Center for the JGOFS International Global Survey of $\mathrm{CO}_{2}$ in the Oceans (poster), PRESENTED AT Ocean Biogeochemistry: A New Paradigm, Bergen, Norway.

Kozyr, A. 2001. Electronic Tour Through the Carbon Dioxide Information Analysis Center's Ocean Web Page, PRESENTED AT Tenth Annual Meeting, North Pacific Marine Science Organization, Victoria, British Columbia, Canada.

Kozyr, A., and T.A. Boden. 2000. Data Management Provided by the Carbon Dioxide Information Analysis Center for the U.S. Department of Energy $\mathrm{CO}_{2}$ Ocean Survey During WOCE/JGOFS Cruises (poster), PRESENTED AT International Symposium on Carbon Cycle in the North Pacific, Nagoya, Japan. 
Kozyr, A., T.A. Boden, S.C. Sutherland, and T. Takahashi. 1995. Data Management Support Provided by the Carbon Dioxide Information Analysis Center for the U.S. Department of Energy $\mathrm{CO}_{2}$ Ocean Survey, PRESENTED AT Twenty-First General Assembly, International Association for the Physical Sciences of the Oceans, Honolulu, Hawaii.

Lamb, M.F., C.L. Sabine, R.A. Feely, F.J. Millero, R. Wanninkhof, R.M. Key, G.C. Johnson, K. Lee, T. Peng, A. Kozyr, J.L. Bullister, and D. Greeley. 2000. Consistency and Proposed Adjustments of Pacific Ocean $\mathrm{CO}_{2}$ Survey Data (poster), PRESENTED AT American Geophysical Union, Fall Meeting, San Francisco.

Lamb, M.F., C.L. Sabine, R.M. Key, J.L. Bullister, F.J. Millero, R. Wanninkhof, T.-H. Peng, A. Kozyr, and R.A. Feely. 2000. Dissolved Inorganic Carbon Crossover Points in the Pacific Ocean, PRESENTED AT 2000 Ocean Sciences Meeting, San Antonio, Texas.

Marland, G., and R. Andres. 1994. Historic Patterns of $\mathrm{CO}_{2}$ Emissions from Fossil Fuels: Implications for Stabilization of Emissions, PRESENTED AT Annual Meeting and Exhibition, Air and Waste Management Association, Cincinnati, Ohio.

Marland, G., R. Andres, and T.A. Boden. 1994. Magnitude and Trends of $\mathrm{CO}_{2}$ Emissions, PRESENTED AT Global Climate Change Science, Policy, and Mitigation Strategies, Phoenix, Arizona.

Marland, G., and T.A. Boden. 1996. $\mathrm{CO}_{2}$ Emissions: Where We Are and How We Got There, PRESENTED AT U.S. Global Change Research Program Seminar Series, Washington, D.C.

Marland, G., and T. Boden. 2001. The Increasing Concentration of Atmospheric $\mathrm{CO}_{2}$ : How Much, When, and Why?, PRESENTED AT 26th Erice International Seminar on Planetary Emergencies, Erice, Sicily, Italy.

Marland, G., T. Boden, A. Brenkert, and R.J. Andres. 1998. Historical and Projected Global Greenhouse Gas Emissions, PRESENTED AT Global Climate Change: Science, Policy, and Mitigation/Adaptation Strategies, Washington, D.C.

Marland, G., A.L. Brenkert, and J. Olivier. 1997. $\mathrm{CO}_{2}$ from Fossil Fuel Burning: A Comparison of ORNL and EDGAR Estimates of National Emissions, PRESENTED AT IPCC Expert Workshop on Uncertainties in Greenhouse Gas Emissions Inventories, Bilthoven, The Netherlands.

Peterson, T.C., D.R. Easterling, R.S. Vose, and J.K. Eischeid. 1993. The Global Historical Climatology Network Precipitation Data, PRESENTED AT Symposium on Precipitation and Evaporation, Bratislava, Slovakia.

Peterson, T.C., D.R. Easterling, R.S. Vose, and J.K. Eischeid. 1994. Homogeneous Global Mean Temperature Time Series, PRESENTED AT Sixth Conference on Climate Variations, Nashville, Tennessee.

Peterson, T.C., and R.S. Vose. 1992. The Global Historical Climatology Network: Present and Future, PRESENTED AT Seventeenth Annual Climate Diagnostics Workshop, Norman, Oklahoma.

Sabine, C.L., R.A. Feely, R.M. Key, F.J. Millero, R. Wanninkhof, T. Peng, A. Kozyr, J.L. Bullister, K. Lee, and M.F. Lamb. 2000. Anthropogenic $\mathrm{CO}_{2}$ Distributions in the Pacific, PRESENTED AT American Geophysical Union, Fall Meeting, San Francisco.

Sabine, C.L., R.M. Key, J.L. Bullister, R.A. Feely, M.F. Lamb, F.J. Millero, R. Wanninkhof, T.-H. Peng, K. Lee, and A. Kozyr. 2001. Anthropogenic Tracers in the Pacific Ocean, PRESENTED AT Biennial Scientific Meeting of The Oceanography Societyl, Miami Beach, Floria.

Schlamadinger, B., and G. Marland. 1997. Net Effect of Forest Harvest on $\mathrm{CO}_{2}$ Emissions to the Atmosphere: A Sensitivity Analysis on the Influence of Time, PRESENTED AT Fifth International Carbon Dioxide Conference, Cairns, Australia.

Stoss, F.W. 1991. The Carbon Dioxide Information Analysis Center: Providing Information About Global Change (poster), PRESENTED AT Annual Meeting, American Association for the Advancement of Science, Washington, D.C.

Stoss, F.W. 1991. CDIAC: Responding to Changing Information Needs, PRESENTED AT Eighty-Fourth Annual Meeting and Exhibition, Air and Waste Management Association, Vancouver, Canada.

Stoss, F.W. 1992. The Carbon Dioxide Information Analysis Center: Providing Support for DOE's Global Change Research Program, PRESENTED AT InfoTech '92, Oak Ridge, Tennessee. 
Stoss, F.W. 1994. CDIAC Data and Information in Support of the U.S. Global Change Research Program, PRESENTED AT National Actions for International Commitment: Evaluating National Climate Change Action Plans, Washington, D.C.

Stoss, F.W. 1994. Citation of Technical Data: Giving Credit Where Credit's Due, PRESENTED AT Practical Conference on Communication, Oak Ridge, Tennessee.

Stoss, F.W. 1994. Global Change Information Resources and Management Strategies: An Introduction, PRESENTED AT Annual Meeting, Special Libraries Association, Atlanta, Georgia.

Stoss, F.W. 1994. Information Management for Global Environmental Change, PRESENTED AT Annual Meeting and Exhibition, Air and Waste Management Association, Cincinnati, Ohio.

Stoss, F.W. 1994. Information Resources for Global Change, PRESENTED AT Second Annual Workshop, Fish and Wildlife Information Managers, Mountain Lake, Virginia.

Stoss, F.W. 1994. The National Library for the Environment: Implications for the Technical Information Community, PRESENTED AT InfoTech '94, Oak Ridge, Tennessee.

Stoss, F.W. 1995. CDIAC Data and Information for Global Climate Change, PRESENTED AT Earth Fair '95: Celebrating the TwentyFifth Anniversary of Earth Day, Washington, D.C.

Stoss, F.W. 1995. The Global Change Data and Information System: An Overview, PRESENTED AT Global Change Data and Information: The Roles of Libraries, Chicago, Illinois.

Stoss, F.W. 1995. Information Resources for Environmental Policy Research, PRESENTED AT Environmental Policy Workshop, Knoxville, Tennessee.

Stoss, F.W., and T.A. Boden. 1993. The Carbon Dioxide Information Analysis Center: Providing Information Support for Global Change Research, PRESENTED AT Consortium for International Earth Science Information Network Users' Workshop, Atlanta, Georgia.

Stoss, F.W., and S.B. Jones. 1993. Performance of the Carbon Dioxide Information Analysis Center (CDIAC), PRESENTED AT InfoTech '93, Oak Ridge, Tennessee.

Stoss, F.W., and S.B. Jones. 1995. Quantification of Data Center Use, PRESENTED AT GCDIS Data Centers Workshop 1995: User Services, Oak Ridge, Tennessee.

Vose, R.S. 1992. Compilation of Long-Term Monthly Temperature, Precipitation, and Pressure Data Sets, PRESENTED AT Annual Meeting, Association of American Geographers, San Diego, California.

Vose, R.S. 1994. The Global Historical Climatology Network, Version 2.0, PRESENTED AT Nintieth Annual Meeting of the Association of American Geographers, San Francisco, California.

Vose, R.S., T.C. Peterson, R.L. Schmoyer, and J.K. Eischeid. 1995. The Global Historical Climatology Network: A Preview of Version 2 (poster), PRESENTED AT Ninth Conference on Applied Climatology, Dallas, Texas.

Vose, R.S., T.C. Peterson, R.L. Schmoyer, J.K. Eischeid, P.M. Steurer, R. Heim, and T.R. Karl. 1993. The Global Historical Climatology Network: Long-Term Monthly Temperature, Precipitation, and Pressure Data, PRESENTED AT Fourth Symposium on Global Change Studies, Anaheim, California.

White, T.W., R.M. Cushman, and V.M. Gornitz. 1990. The Global Coastal Hazards Data Base (poster), PRESENTED AT Tenth Annual Environmental Systems Research Institute User Conference, Palm Springs, California.

White, T.W., V.M. Gornitz, R.M. Cushman, and P. Kanciruk. 1989. Developing a Global Coastal Hazards Data Base Using ARC/INFO (poster), PRESENTED AT Ninth Annual Environmental Systems Research Institute User Conference, Palm Springs, California.

\section{Awards}

ARM Outreach. 1992. Achievement Award for Promotional Materials, AWARDED BY East Tennessee Chapter of the Society for Technical Communications. 
Atmospheric Carbon Dioxide Mixing Ratios from the NOAA Climate Monitoring and Diagnostics Laboratory Cooperative Flask Sampling Network. 1996. Achievement Award for Technical Reports, AWARDED BY East Tennessee Chapter of the Society for Technical Communications.

Carbon-14 Measurements in Atmospheric $\mathrm{CO}_{2}$ from Northern and Southern Hemispheric Sites, 1962-1993. 1997. Merit Award for Technical Reports, AWARDED BY East Tennessee Chapter of the Society for Technical Communications.

Carbon Dioxide, Hydrographic, and Chemical Data Obtained During the R/V Meteor Cruise 18/1 in the North Atlantic Ocean. 1997. Excellence Award in Online Documentation, AWARDED BY Atlanta Chapter of the Society for Technical Communications.

Carbon Dioxide Information Analysis Center. 1993. Exceptional Public Service Award, AWARDED BY U.S. Department of Energy.

Carbon Dioxide Information Analysis Center. 1995. Certificate of Appreciation, AWARDED BY U.S. Department of Energy, Office of Energy Research.

Catalog of Databases and Reports. 1998. Excellence Award for Informational Materials, AWARDED BY East Tennessee Chapter of the Society for Technical Communications.

CDIAC Catalog of Numeric Data Packages and Computer Model Packages. 1993. Achievement Award for Catalog Design, AWARDED BY East Tennessee Chapter of the Society for Technical Communications.

CDIAC Catalog of Numeric Data Packages and Computer Model Packages. 1993. Merit Award for Promotional Brochures, AWARDED BY East Tennessee Chapter of the Society for Technical Communications.

CDIAC CD-ROM Flyer. 1993. Merit Award for Informational Brochures, AWARDED BY East Tennessee Chapter of the Society for Technical Communications.

CDIAC CD-ROM Package. 1993. Merit Award for Package Design, AWARDED BY East Tennessee Chapter of the Society for Technical Communications.

CDIAC Communications. 1991. Merit Award for Promotional Materials, AWARDED BY East Tennessee Chapter of the Society for Technical Communications.

CDIAC Communications. 1992. Achievement Award for Newsletters, AWARDED BY East Tennessee Chapter of the Society for Technical Communications.

CDIAC Communications. 1993. Excellence Award for Newsletters, AWARDED BY East Tennessee Chapter of the Society for Technical Communications.

CDIAC Communications. 1994. Excellence Award for Newsletters, AWARDED BY East Tennessee Chapter of the Society for Technical Communications.

CDIAC Communications. 1995. Merit Award for Newsletters, AWARDED BY East Tennessee Chapter of the Society for Technical Communications.

CDIAC Communications. 1996. Achievement Award in Online Documentation, AWARDED BY Atlanta Chapter of the Society for Technical Communications.

CDIAC Communications. 1997. Achievement Award in Online Documentation, AWARDED BY Atlanta Chapter of the Society for Technical Communications.

CDIAC Communications. 1999. Merit Award for Newsletters, AWARDED BY East Tennessee Chapter of the Society for Technical Communications.

CDIAC Communications. 1999. Merit Award for Online Books, AWARDED BY East Tennessee Chapter of the Society for Technical Communications.

CDIAC Communications. 2001. Merit Award in Online Communications, AWARDED BY East Tennessee Chapter of the Society for Technical Communications. 
CDIAC Numeric Data Package. 1993. Achievement Award for Photographs, AWARDED BY East Tennessee Chapter of the Society for Technical Communications.

CDIAC's World-Wide-Web Site. 1996. 3-Star Magellan Site, AWARDED BY The McKinley Group.

CDIAC Web Site. 2001. Merit Award in Online Communications, AWARDED BY East Tennessee Chapter of the Society for Technical Communications.

Data Management Provided by the Carbon Dioxide Information Analysis Center for the U.S. Department of Energy CO ${ }_{2}$ Ocean Survey During WOCE/JGOFS Cruises. 2000. Most Important Poster Award, AWARDED BY International Symposium on Carbon Cycle in the North Pacific.

DOE Research Summary. 1992. Achievement Award for Whole Periodicals, AWARDED BY East Tennessee Chapter of the Society for Technical Communications.

DOE Research Summary. 1993. Achievement Award for Whole Periodicals, AWARDED BY East Tennessee Chapter of the Society for Technical Communications.

DOE Research Summary. 1994. Achievement Award for Newsletters, AWARDED BY East Tennessee Chapter of the Society for Technical Communications.

DOE Research Summary. 1995. Achievement Award for Newsletters, AWARDED BY East Tennessee Chapter of the Society for Technical Communications.

DOE Research Summary. 1996. Merit Award for Publications, AWARDED BY East Tennessee Chapter of the Society for Technical Communications.

DOE Research Summary. 1997. Achievement Award in Online Documentation, AWARDED BY Atlanta Chapter of the Society for Technical Communications.

Estimates of Global Regional and National Annual $\mathrm{CO}_{2}$ Emissions from Fossil-Fuel Burning, Hydraulic Cement Production, and Gas Flaring. 1996. Achievement Award for Technical Reports, AWARDED BY East Tennessee Chapter of the Society for Technical Communications.

Fiscal Year 1999 Annual Report. 2001. Merit Award in Technical Publications, AWARDED BY East Tennessee Chapter of the Society for Technical Communications.

Glossary: Carbon Dioxide and Climate. 1991. Achievement Award for Brochures, AWARDED BY East Tennessee Chapter of the Society for Technical Communications.

Managing Global Change Information. 1996. Achievement Award for Publications, AWARDED BY East Tennessee Chapter of the Society for Technical Communications.

Research Project of the Month. 1991. Merit Award for Whole Periodicals, AWARDED BY East Tennessee Chapter of the Society for Technical Communications.

Selected Translated Abstracts of Chinese-Language Climate Change Publications. 2001. Merit Award in Technical Publications, AWARDED BY East Tennessee Chapter of the Society for Technical Communications.

Surface Water and Atmospheric Underway Carbon Data Obtained During the World Ocean Circulation Experiment Indian Ocean Survey Cruises, RV Knorr, December 1994-January 1996. 1998. Merit Award for Technical Reports, AWARDED BY East Tennessee Chapter of the Society for Technical Communications.

Trends '91: A Compendium of Data on Global Change. 1992. Merit Award for Technical Reports, AWARDED BY East Tennessee Chapter of the Society for Technical Communications.

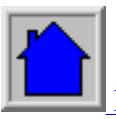

Back to CDIAC Home Page 
rmc 12/01 